\title{
Pamięć i tożsamość ${ }^{1}$
}

\author{
Wrocławski Rocznik \\ Historii Mówionej \\ Wydanie specjane, 2018 \\ ISSN 2084-0578 \\ DOI: 10.26774 /wrhm.219
}

Każde źródło historyczne, wywodzące się z ludzkiego postrzegania, jest subiektywne, jednak tylko źródła oralne pozwalają na zakwestionowanie tej subiektywności; na rozdzielenie warstw pamięci, dotarcie do ich ciemności, z nadzieją na odsłonięcie ukrytej prawdy. Skoro tak, to dlaczego nie skorzystać z tej unikatowej dla historyków szansy, nie ułożyć informatorów na kozetce i - niczym psychoanalitycy - dotknąć ich podświadomości i wyciągnąć z niej najgłębiej skrywane sekrety?

To bardzo kusząca możliwość. Psychoanaliza to magia naszych czasów. Niezwykła moc psychoanalityków - do słuchania i uzdrawiania, do uwalniania za pomocą ekspresji skrywanego gniewu i wstydu z zapomnianej przeszłości, i przynoszenia ukojenia; moc zyskiwania naszej sympatii

Tłumaczenie na podstawie: P.R. Thompson, Memory and the Self, [w:] idem, The Voice of the Past. Oral History, Oxford 2000, s. 173-189. Artykuł został przetłumaczony i przedrukowany za zgodą @ Oxford University Press w imieniu OHA. OUP i OHA nie biorą odpowiedzialności za tłumaczenie tego artykułu. Pełną odpowiedzialność za tłumaczenie ponosi redakcja. Licencja nr 90558664 została udzielona przez (c) Oxford University Press. Artykuł z ograniczonymi prawami autorskimi. Zabrania się swobodnego tworzenia adaptacji, przeróbek i remiksów oraz publikowania, także w celach komercyjnych. Wszystkie prawa zastrzeżone (przyp. red.). 
154 poprzez wysłuchanie nas i później oddawania tej sympatii jako nowo nabytej siły pewności siebie - w skrócie, moc zgłębiania naszej najgłębszej intymności, aby odmienić nasze najbardziej ukryte wewnętrzne „ja”, jest z natury niemożliwa do pełnego przewidzenia ani logicznego zrozumienia. Już samo to sprawia, że jest ona tak samo groźna, jak jest atrakcyjna. Jeśli dodać do tego tajemniczą teorię podświadomości, zbudowaną wokół seksualności, która w naszej kulturze stanowi tabu i jednocześnie jest wynoszona na ołtarze, przestaje dziwić fakt, iż ta moc sprawia, że psychoanalitycy - a jeszcze bardziej psychiatrzy, dysponujący baterią wpływających na umysł leków - są czarownikami i wyroczniami XX w. Szczególnie dla historyków stanowią oni podwójne - zawodowe i osobiste - wyzwanie, w postaci konkurencyjnej dziedziny, oferującej manipulację przeszłością według innych reguł.

Czy nam się to podoba, czy nie, niewielu historyków oralnych będzie kiedykolwiek zdolnych do praktykowania psychoanalizy. Wymaga to bowiem lat zupełnie innego szkolenia. Co równie ważne, wywiady historii mówionej bazują również na zupełnie innych celach; nasi informatorzy nie mogą być poproszeni o położenie się wygodnie na plecach, otwarcie umysłu na swobodne skojarzenia, o mówienie, gdy osoba prowadząca wywiad milczy, czy też o codzienne sprawozdania na temat swoich marzeń i fantazji. Jednak badacze historii mówionej mogą się nauczyć wiele z psychoanalizy na temat potencjału ich własnego zajęcia - zarówno dla siebie samych, jak i dla swych informatorów. Rzeczywiście, rozważania nad implikacjami psychoanalizy bez wątpienia stanowiły silny bodziec do poczynionych w ciągu ostatnich dziesięciu lat postępów w naszym rozumieniu pamięci ustnej jako świadectwa.

W wielu wypadkach najbardziej bezpośrednią przyczyną zainteresowania się psychoterapią jest osobiste doświadczenie terapii. Wspaniały przykład daje na to jeden z czołowych badaczy historii mówionej, Ronald Fraser, w publikacji In Search of a Past z 1984 r. Jest to wyjątkowe, oryginalne i fascynujące dzieło, które samo w sobie mogłoby stanowić element historii społecznej. Fraser przeprowadził wywiady ze służbą zatrudnioną u jego rodziców. Przyjmując ich perspektywę, dokonuje rekonstrukcji świata społecznego klasy wyższej z okołolondyńskich hrabstw w latach 30. XX w. i zmian związanych ze zniesieniem w czasie II wojny światowej podziałów klasowych i prześladowań. Słowa służących dość wymownie świadczą o złożonej mieszance lojalności i wrogości, która wiązała zarówno służących między sobą, jak i z pracodawcą. Oddają też chłodno obraz emocjonalnej pustki zamieszkującej rezydencję rodziny - małżeństwa pozbawionego miłości i ich samotnego, aroganckiego syna. Odwaga i oryginalność 
Frasera polega jednak na połączeniu i spleceniu tych bolesnych wspomnień z dzieciństwa z dwoma innymi dialogami: ze swoim ojcem, dawniej apodyktycznym, a obecnie pełnym żalu i zadziwienia, którego umysł uległ dezintegracji w zlepek luźno połączonych fragmentów wspomnień, oczekującym na swój koniec w domu opieki; oraz z dyskusją z psychoanalitykiem na temat własnych wspomnień. Rezultatem jest zupełnie nowa forma autobiografii, stawiająca czoła ważnym problemom epoki i podziału klasowego, a jednocześnie do głębi osobista ${ }^{2}$.

Jest to również fuga o naturze pamięci. Zestawienie pozornie bezpośrednich świadectw historii życia służby ukazuje ich własne przemilczenia i uniki, na przykład na temat kontaktów seksualnych pomiędzy nimi; jest to przeciwstawione pamięci starca, będącej w stanie silnego wyniszczenia, co może czekać też ich umysły; i to dostarcza Fraserowi materiału do odkrycia jego własnej podświadomej pamięci podczas psychoanalizy. Na przykład: to jego niania powiedziała Fraserowi o tym, że karmiono go i przewijano o z góry ustalonych porach i sadzano na nocniku, od kiedy skończył cztery miesiące: „Przywiązywałam cię później na nocniku do brzegu łóżka do czasu, aż się załatwiłeś". Dzięki terapii Fraser nie tylko uwalnia swój gniew w stosunku do rodziców, lecz również zaczyna pojmować to, że społeczny podział na pracodawców i służbę w jego rodzinnym domu spowodował także podział emocjonalny, który Fraser przeniósł w swoje dorosłe życie. Jego surowa, praktyczna niania była dla niego matką w podobnym stopniu, jak jego nieobecna, piękna matka; podczas gdy pełen niechęci ogrodnik, który tak nienawidził cichej arogancji jego ojca, stał się najbliższym towarzyszem samotnego chłopca; słuchał go i uczył, jak sadzić rośliny i szanować pracę rąk - był niczym drugi ojciec. To właśnie ogrodnik, poprzez emocjonalne przywiązanie chłopca do człowieka pracy, nieświadomie otworzył przed nim polityczną ścieżkę, którą Fraser obrał dużo później, gdy odrzucił wartości swojej klasy społecznej wraz z tymi, które wyznawał jego niedostępny ojciec.

A zatem, choć z początku wydawało się, że psychoanalityk szuka w pamięci Frasera czegoś innego, niż to, czego on sam szukał jako historyk, że odsuwa na bok snucie teorii, świat materialny czy rzeczywisty bieg wydarzeń, by skupić się na odczuciach dotyczących przeszłości, na relacjach

Innym przykładem publikacji, w której połączone są wspomnienia zbiorowe i indywidualne, i która bazuje zarówno na pamiętnikach, jak i na ustnych świadectwach, jest praca Luisy Passerini, Autobiography of a Generation: Italy, 1968, Hanover 1996. 
międzyludzkich, to pod koniec tej „wyprawy do wewnętrznego odkrycia” te dwa wymiary rozumienia stały się poprzez analizę częściami jednej interpretacji ${ }^{3}$. Nie oznacza to jednak, że do takiej interpretacji dojść można wyłącznie za pośrednictwem psychoanalizy. Standardowo taki rezultat uzyskuje się też podczas zajęć grupowych w ramach terapii rodzinnej, gdzie wydobywa się skrywane uczucia poprzez konfrontację z innymi członkami rodziny w sytuacji, w której wyrażenie takich uczuć jest bezpieczne, a nawet oczekiwane. Techniki wolnych skojarzeń i analizy snów nie są częścią tego podejścia terapeutycznego. Mimo wszystko sprawdza się to w odkrywaniu złożoności sprzecznych emocji, przeplatających się miłości i gniewu, charakterystycznych dla bliskich relacji. Takie podejście jest jeszcze skuteczniejsze - poprzez wnioski wypływające z systemowej teorii rodziny, która bada charakter relacji - we wskazywaniu równie charakterystycznych międzypokoleniowych wpływów na wzorce emocjonalne ${ }^{4}$.

Jako przykład może posłużyć przypadek pięknej nastoletniej córki biznesmena z północnych Włoch, która powoli głodziła się na śmierć. Przeciw czemu protestowała? Rodzina nie potrafiła tego zrozumieć, a szkoła, gdzie dziewczyna ciężko pracowała i osiągała dobre wyniki, również nie mogła dostarczyć żadnych wskazówek. Zdesperowana rodzina zasięgnęła pomocy u znanego charyzmatycznego terapeuty $\mathrm{z}$ wielkiego miasta. Ich początkowe relacje na temat siebie nawzajem były dość oszczędne: dzieci uważały, że ich matka mogłaby być może bardziej niezależna; podczas gdy ona uważała, że jej mąż jest dobrym człowiekiem, którego jedynym problemem było to, że nigdy się nie śmiał, zawsze był poważny i zasępiony. Jednak zaledwie godzina $\mathrm{w}$ gabinecie terapeuty wystarczyła, by ujawnić rodzinne sekrety, które paraliżowały ich wszystkich. Mąż, który pochodził z dobrej rodziny, poślubił pokojówkę swojego ojca po tym, gdy ta zaszła z nim w ciążę. Dla niego romans stanowił bunt przeciwko ojcu, który zdominował jego świątobliwą, pogrążoną w depresji matkę; dla niej związek był wyzwoleniem z biedy. Zamiast jednak uciec, małżeństwo wpadło w pułapkę problemów swoich rodziców, przerzucając te problemy na własne dzieci. On postąpił honorowo, jednak nigdy nie wybaczył żo-

R. Fraser, In Search of a Past, London 1984, s. 85, 118.

G.G. Barnes, Systems Theory and Family Therapy, [w:] Modern Child Psychiatry, red. M. Ruttner, L. Hersnov, London 1985, s. 216-229; J. Holmes, Family and Individual Therapy: Comparisons and Contrasts, „British Journal of Psychiatry”, nr 47 (1985), s. $668-676$. 
nie uwiedzenia go i zniszczenia mu życia. Wolał spędzać czas ze swoimi rodzicami i dzielić ich pogardę dla la serva. Ona uważała, że mąż zawsze był srogi, że był wobec niej surowy i nie zważał na jej problemy, a jego ledwo skrywany gniew wpędził ją w nawracającą depresję. Mąż uważał swoją żonę za przesadnie emocjonalną, czego nie mógł znieść i miał dość problemów jej rodziny. Ich dzieci skarżyły się, że matka płacze i krzyczy. Zamiast emocjonalnie oddać się sobie jako para, zarówno mąż, jak i żona od samego początku byli przywiązani do rodzin, z których pochodzili. Jej rodzina nie tylko była na niższym szczeblu społecznym niż jego, ale też pozostała dużo uboższa, a największym żalem żony do męża była jego odmowa dawania pieniędzy na pomoc jej siostrom, podczas gdy on postrzegał jej rodzinę jako bez końca wyciągającą jego środki i zawsze proszącą o więcej. Mimo to mąż nalegał, by jego żona co niedzielę gotowała posiłek dla jego rodziców, którzy podzielali jego niechęć do niej i jej podobnych. W tym impasie antagonizmów emocjonalnych i klasowych niedzielne obiady stanowiły formę nienawiści. Choć żadne z nich wcześniej tego nie widziało, teraz stało się jasne, że odmawianie jedzenia przez dziewczynę było protestem przeciwko ukrytemu, ale nieznośnemu konfliktowi między jej rodzicami. Jej działanie stanowiło lustrzane odbicie tego konfliktu: zamiast jedzenia jako nienawiści - głodowanie jako miłość.

Terapia rodzinna to kolejna sytuacja, w której skrywane prawdy objawiają się szybciej niż w wypadku psychoanalizy. Ma ona przewagę interpretowania indywidualnych potrzeb nie w izolacji, ale w społecznym kontekście. Z perspektywy terapii rodzinnej możemy zbadać, dlaczego w jednej rodzinie każde pokolenie synów jest w konflikcie z ojcami, a w innej przekazuje się umiejętności i ambicje odniesienia sukcesu w konkretnym rodzinnym zawodzie; dlaczego w jednej rodzinie ani ojcowie, ani synowie nie potrafią oddać się stałemu, poważnemu związkowi i muszą zawsze mieć kochanki, w innej dominują silne kobiety, mężczyźni zaś przewijają się jak postacie epizodyczne, a w jeszcze innej pogrążone w depresji matki pozostawiają po sobie pogrążone w depresji córki. Takie badanie różnorodności zwykłych doświadczeń okazuje się zdecydowanie bardziej owocne niż surowe zastosowanie indywidualnej teorii psychoanalizy do całych kultur, co niestety do tej pory charakteryzowało „psychohistorię”. Ta technika jest również

T. Ashplant, Psychoanalysis in Historical Writing, „History Workshop”, nr 26 (1988), S. 102-119. 
znacznie bliższa ogromnej różnorodności indywidualnych doświadczeń, na którą zwykle natrafiają badacze historii mówionej i którą muszą wyjaśnić. Jedną z ważniejszych lekcji, jakie można wynieść z obu rodzajów terapii, jest potrzeba zwiększenia historycznej wrażliwości na siłę emocji, podświadomych pragnień, odrzucenia i imitacji, które stanowią integralną część struktury zwykłego życia społecznego oraz przekazywania tej struktury z pokolenia na pokolenie.

Podobnie, to również nie konkretne techniki psychoanalizy liczą się najbardziej w interpretacji snów, a uwaga, jaką taka psychoanaliza otacza wszechobecność symbolizmu w naszej świadomości. Moglibyśmy zatem prosić naszych informatorów o opisanie ich snów, ich nocnych koszmarów, ich fantazji powstałych, gdy przy taśmie produkcyjnej śnili na jawie; a żeby jak najwięcej wynieść z takich przejawów wewnętrznych pragnień i trosk, powinniśmy rzecz jasna tropić typowe sztuczki wyobraźni, kondensację informacji, odwrócenia wartości, zastąpienia, metafory, zabawy słowem, a także obrazy, poprzez które sny przekazują swoje symboliczne znaczenie. Te sztuczki są jedną z przyczyn przerażającej mocy fantazji i koszmarów. Jednakże równie satysfakcjonująca jest wiedza, że te narzędzia dają również standardowe wskazówki kierujące ku symbolicznemu znaczeniu świadomie przekazywanych komunikatów: zwyczajów społecznych, takich jak hałasowanie na demonstracjach, dowcipów czy też tradycyjnych mitów i osobistych historii.

W jeszcze bardziej bezpośredni sposób uwagę na fundamentalną rolę języka jako części tego symbolizmu skierowała reinterpretacja Freudowskiej psychoanalizy przez Jacquesa Lacana. Uważał on, że nieświadomość zbudowana jest jak język, a nabywanie tożsamości seksualnej i osobistej uznawał za jednoczesny i zawsze niepewny proces, którego fundamenty kładzie się w momencie, gdy niemowlę styka się z językiem poprzez odbieranie i słuchanie mowy oraz naukę mówienia. Męskość i żeńskość są zatem narzucone psychice dziecka na długo przed tym, jak różnice w płci zaczynają mieć jakiekolwiek znaczenie, poprzez nieświadomy, społeczny symbolizm płci wyrażanej w języku. Dokonane przez Lacana przeformułowanie Freudowskiej, zasadniczo męskiej perspektywy na rozwój ludzkiej osobowości, jest mniej radykalne, niż te proponowane wcześniej przez Kleina i Chodorowa, a jako teoria - po części przez to, że przeformułowanie to 
wyłożone zostało za pomocą umyślnie niezrozumiałego, „symbolicznego” języka - znacznie słabiej opiera się argumentom logicznej krytyki'

Niemniej jednak w dużym stopniu pomogło to feministkom w ukazaniu nieadekwatności bezpośrednich wniosków wyciąganych z różnic w osiągnięciach społecznych mężczyzn i kobiet oraz hipokryzji polityki równych szans, która ignoruje wagę kultury. Już w pierwszych momentach kształtowania swojej społecznej świadomości dziewczynki dowiadują się, że są kobietami wchodzącymi w świat kultury, która faworyzuje męskość, a zatem i mężczyzn, tak jak w samym języku forma męska zawsze będzie miała pierwszeństwo, jako forma standardowa, a forma żeńska dodana będzie jako wyjątek. Aby zająć pozytywne miejsce w świecie kultury, dziewczynki muszą walczyć od samego początku, ale jest to nierówna walka. W kulturach posługujących się ideograficznym pismem, te same lekcje utrwalane są po raz drugi, gdy dziewczynki uczą się odczytywać pismo: mała Chinka wówczas odkryje, że symbol oznaczający mężczyznę zapisuje się za pomocą symboli oznaczających pole oraz siłę, natomiast kobietę - krosno lub łono.

Internalizacja takich postaw równie wyraźnie ujawnia się w różnicach między sposobami przywoływania przeszłości przez kobiety i mężczyzn. Nie chodzi tylko o to, że ich wspomnienia zdają się skupiać na czymś innym, że mężczyźni chętniej opowiadają o pracy, a kobiety o życiu rodzinnym, oraz że kobiety z większą łatwością opowiadają o zapamiętanych emocjach niż mężczyźni. W różny sposób posługują się oni też językiem. Już w dzieciństwie dziewczynki bardziej niż chłopcy skłonne są do szczegółowego opisywania wypowiedzi innych. A wśród starszych kobiet i mężczyzn, co zaobserwowała Isabelle Bertaux-Wiame wśród migrantów do Paryża z francuskich wsi, „mężczyźni uznają przeżyte przez siebie życie za ich własne”, za serię świadomych działań, zgodnych z określonymi celami, a opowiadając swoją historię, używają oni aktywnej pierwszej osoby „ja”, przyjmując siebie samego za podmiot swoich działań już poprzez formy językowe, jakich używają. Kobiety natomiast opowiadają o swoim życiu zwykle z perspektywy relacji, uwzględniając fragmenty innych historii życiowych w swojej własnej; bardzo często wypowiadają się jako „my” lub używają bezosobowej formy „się” (w języku francuskim - on), co symbolizuje relację leżącą u podstaw danej części ich życia: „my” jako „moi rodzice

J. Mitchell, Psychoanalysis and Feminism, London 1974; N. Chodorow, The Reproduction of Mothering, Berkeley 1978. 
160 i ja” lub „mój mąż i ja” albo „ja i moje dzieci”". Odczytywane w tym świetle historie życia ujawniają nieoczekiwane i ważne nowe przekazy.

Wreszcie: więcej możemy zrozumieć z tego, co niewypowiedziane. Znowuż, to nie konkretne teorie psychoanalizy okazują się najbardziej użyteczne, a nowy rodzaj wrażliwości, umiejętność dostrzegania tego, co zostało pominięte. Oryginalne przekonanie Freuda o pamięci absolutnej wygląda obecnie jak dziewiętnastowieczne pobożne życzenie odzyskania przeszłości i z pewnością nie jest naukowo udowodnione, pomimo bycia tak popularnym, że powszechne jest obecnie przekonanie, że „wszystkie wspomnienia są potencjalnie odzyskiwalne" . Freud niemal z pewnością mylił się, wyjaśniając brak wspomnień z wczesnego dzieciństwa wyparciem: znacznie bardziej prawdopodobne jest, że doświadczenia z okresu niemowlęcego nie pozostają w pamięci dlatego, że pamięć długotrwała nie jest jeszcze zorganizowana, a nie zaś w wyniku stłumienia tych wspomnień z powodu ich wstydliwej natury. Nie pomoże nam również zbytnio zastanawianie się, czy typowy „opór” osoby analizowanej - tajemniczość, skrycie, upartość - mógłby być zrozumiany przez analogię do doświadczanej w dzieciństwie odmowy jedzenia czy odstawienia od piersi albo załatwienia potrzeb fizjologicznych w odpowiednim miejscu. Ważne, by nauczyć się wypatrywać tego, co niewypowiedziane i zastanawiać się nad rangą milczenia. Najbardziej przekonywającymi znaczeniami mogą okazać się te najprostsze.

Krótko mówiąc: psychoanaliza pozwala nam zyskać większe wyczulenie na niuanse pamięci i komunikacji, ale nie zapewnia nam klucza do ukrytej komnaty. To, co na ogół podlega wyparciu, jest zwykle również ogólnie obecne, tak jak seks. To, co skrywa nieświadomość, może różnić się pod względem proporcji i mocy, jednak nie pod względem rodzaju: to zawsze jest po prostu ludzkie doświadczenie, zapomniane przypadkowo lub celowo z powodów, które zostały wymienione wyżej. Ocaleli z obozów koncentracyjnych śnią o jedzeniu i torturach. Prawdziwy świat kształtuje urojenia nawet całkiem obłąkanych jednostek. Schizofrenicy z epoki wiktoriańskiej tkali swoje fantazje wokół religii, a współcześni fantazjują o seksie, jednak obie grupy czerpią z codziennych problemów swoich czasów. Fantazje i nieświadomość

R. Ely, A. McCabe, Gender Differences for Speech, [w:] Gender and Memory, red. S. Lydesdorff, L. Passerini, P. Thompson, Oxford 1996, s. 17-30; I. Bertaux-Wiame, The Life History Approach to the Study of Internal Migration, [w:] Our Common History, red. P. Thompson, London 1982, s. 192-193.

D. Lowenthal, The Past is a Foreign Country, London 1985, s. 17. 
są w końcu niczym więcej, jak przearanżowaniem życia. Czasami mogą ukazywać świat do góry nogami i z pewnością mają moc zmiany zachowań jednostki w rzeczywistości. Nieświadomość jest siłą stojącą za każdą historią życia. Forma, z której odlana jest cywilizacja i jej narzekania, jest dostatecznie wyraźna, nieważne, z której strony świadomości ją postrzegamy.

Istnieje jednakże jeszcze inny wymiar psychoanalizy, który wymaga podobnego zainteresowania ze strony badaczy historii mówionej. Chodzi o podstawowy proces terapeutyczny poprzez uwalnianie wspomnień. Wielu historyków oralnych zdało sobie z tego sprawę przypadkiem, w trakcie wykonywania swojej pracy. Uświadamiali sobie - często przez osobę trzecią - że udzielanie wywiadu dawało osobom starszym poczucie ważności i celu, stanowiło dla nich coś wyczekiwanego, a nawet dawało siłę do pokonania chorób i odżycia na nowo. Mogli się również przekonać, że nie zawsze jest to takie proste.

Większość ludzi skrywa w sobie wspomnienia, które po przywołaniu wzbudzają silne emocje. Mówienie o zmarłej matce czy ojcu może wywołać łzy lub gniew. Zwykle w takiej sytuacji wystarcza pozbawiona zażenowania reakcja współczucia: już samo wyrażenie tych emocji będzie miało pozytywny efekt. Z praktyki wynika również, że zwykle możliwe jest, a nawet pomocne, aby badacz historii mówionej wysłuchał wspomnień o szczególnie traumatycznych doświadczeniach, na przykład o gwałcie czy uwięzieniu w obozie koncentracyjnym. W niektórych przypadkach jednak wspomnienia mogą odkryć tak głęboki ból, którym nikt się nigdy nie zajął, że konieczna będzie pomoc profesjonalnego terapeuty, a najlepsze, co badacz historii mówionej może w takim wypadku zrobić, jest zasugerowanie, gdzie taką pomoc można znaleźć. Istnieją pewne sygnały alarmowe, na które należy być uważnym, takie jak ogólna niespójność, długie chwile ciszy, powtarzanie tej samej historii związanej z szokiem i przerażeniem czy wybuchy gniewu lub płaczu, drżenie lub zgarbiona postura. Takie niedające spokoju wspomnienia wynikają zwykle z doświadczeń życia rodzinnego, które są związane z przemocą, wstydem albo są szczególnie zagmatwane lub kłopotliwe, bądź wynikają z okrucieństw wojny i prześladowań9.

J.L. Herman, Trauma and Recovery: From Domectic Abuse to Political Terror, New Your 1992; L. Hunt, M. Marshall, Ch. Rowlings, Past Trauma in Late Life: Perspectives on Therapeutic Work with Older People, London 1997; G. Ben-Ecer, Trauma and Trauma Signals in the Narratives of Migration Journey of Ethiopian Jews to Israel, [w:] Trauma and Life Stories, red. K.L. Rogers, S. Leydesdorff, G. Dawson, London 1999. 
Donald i Lorna Millerowie nagrali wspomnienia ocalałych z „pierwszego ludobójstwa w XX w.", masakry ponad miliona Ormian - połowy ich populacji w Imperium Osmańskim - która wydarzyła się w latach 1915-1922. Niektórych palono żywcem, innych wykorzystywano jako zwierzęta juczne, okaleczano, torturowano i głodzono na śmierć. Ciężarnym kobietom rozcinano brzuchy, matki zmuszane były do pozostawienia swoich małych dzieci na pewną śmierć na skałach i w strumieniach lub do sprzedania ich przejezdnym Arabom; niejedna matka i niejedna rodzina popełniały zbiorowe samobójstwa. Co taki niewyobrażalny koszmar pozostawił w pamięci ocalałych? Niektórzy nigdy nie będą chcieli o tym mówić. U niektórych gniew ustąpił politycznym usprawiedliwieniom, rezygnacji, bo przecież nikogo to nie obchodzi; czasem nawet przebaczeniu. U innych jednak nienawiść do Turków nie traci na sile, śnią o byciu ściganymi: „budzę się zlany potem”, „dźgają cię w plecy”. Inni mimo wszystko wciąż mają nadzieję na zemstę: w 1973 r. 78-letni ocalały, który w rzezi stracił niemal całą rodzinę, zastrzelił w kawiarni w Santa Barbara w Kalifornii dwóch tureckich urzędników konsulatu ${ }^{10}$. Jego wściekłość była wspomnieniem, które przetrwało ponad 50 lat w innej kulturze i na innym kontynencie.

Wspomnienia jeszcze bardziej zorganizowanej degradacji, poniżenia i eksterminacji, obecne w ocalałych z nazistowskich obozów koncentracyjnych, prześladują w równym stopniu. Dwustu włoskich ocalałych zeznało, że wielu z nich zachowywało te wspomnienia dla siebie, bo uważali, że cała ta groza byłaby dla innych nie do uwierzenia, nie do opisania słowami i zbyt bolesna dla ich bliskich: to, jak odizolowano ich od wszystkich, których znali, jak odebrano im wszystko, co mieli, rozebrano ich do naga i zgolono wszystkie włosy, nadano numery zamiast imion, zmuszono do jedzenia rękami „come una bestia”, jak każdego dnia żyli otoczeni widokiem i odorem śmierci, jak czuli zapach spalonych zwłok, widzieli ludzkie prochy używane do pokrywania dróg i sterty martwych ciał; jak nauczyli się jeść trawę, by poskromić głód, okradać każdego i nie ufać nikomu poza najbliższymi, spać spokojnie zaraz obok zwłok towarzyszy, którym wcześniej zabierali ubrania, by samemu ochronić się od zimna; a ponad wszystko - myśleć o śmierci, jak o czymś zwyczajnym, nawet kiedy strażnicy na ich oczach bili innych więźniów na śmierć, rozbijając im głowy... Nic dziwnego, że

D. Miller, L. Miller, Survivors: An Oral History of the Armenian Genocide, Berkeley 1993. 
nawet dziś ceną opowiedzenia o tym mogą być tygodnie obudzonych na nowo koszmarów. Takie wspomnienia mogą być podobnie nieznośne nawet pośrednio. Claudine Vegh odkryła podobne lęki, koszmary, nerwowość, gniew i paraliż u francuskich Żydów, z którymi przeprowadzała wywiady, a których rodzice zostali zabici w okresie nazistowskim. „Wielu z spośród osieroconych, nigdy nie mówi o swojej przeszłości, jest to temat tabu [...] Nie chcą, ale przede wszystkim nie potrafią o tym mówić”. Wielu z tych, którzy zdecydowali się mówić, było bardzo opornych, mówiło chrypliwym szeptem czy wybuchało płaczem. Nie mieli oni możliwości przeżyć żałoby w momencie rozłąki z rodzicami, bo nie było na to czasu, nie odprawiono żadnych obrzędów, a śmierci rodziców nie byli pewni jeszcze długo po tym, gdy ona nastąpiła. Nie dano im możliwości pogodzenia się. Weszli w sędziwy wiek z otwartą raną, z bezładem straty, wstydu, gniewu i poczucia winy tak realnymi dziś, jak w przeszłości: z „niemą agonią”, która „nawiedzała ich przez całe życie, [...] z bólem tak dokuczliwym, tak wszechobecnym i wszechogarniającym, że mówienie o nim wydaje się niemożliwe nawet pół życia później"11.

Takie wspomnienia są równie ważne, co groźne, i wymagają od słuchacza specjalnych umiejętności. Na szczęście są to przypadki szczególne. Dla większości ludzi ból związany z przeszłością da się znacznie łatwiej opanować; leży on zaraz obok przyjemnych wspomnień związanych z zabawą, pozytywnymi emocjami i osiągnięciami, a przywołanie obu typów wspomnień może mieć pozytywny efekt. Przypominanie sobie własnego życia ma zasadnicze znaczenie dla naszego poczucia własnej tożsamości; praca nad tymi wspomnieniami może wzmocnić lub pomóc odzyskać pewność siebie. Terapeutyczny wymiar pracy nad własną historią odkrywany był wielokrotnie. Arthur Ponsonby, krytyk literacki i autor antologii pt. English Diaries z 1923 r., zauważył, że wielu z autorów zebranych przez niego tekstów wykorzystywało pamiętniki jako narzędzie do „autoanalizy, wnikliwego badania siebie, wglądu w głąb samych siebie, [...] w celu oczyszczenia umysłu, wymiecenia ludzkich problemów, podsumowania sytuacji. [...] Mogą przy tym doznać nawet takiej samej ulgi, jaką niektórzy odnajdują w modlitwie”. Socjologowie również zauważyli "spowiedniczy” charakter wywiadów dotyczących historii życia,

A. Bravo, D. Jalla, La vita offensa, Milan 1986, s. 160; A. Bravo, Italian Women in the Nazi Camps, „Oral History”, 13 (1985), nr 1, s. 20-27; C. Vegh, I Didn't Say Goodbye, London 1984, s. 29, 161. 
164 a ponieważ przez znaczną część swojej pracy mieli do czynienia z dewiantami, często izolowanymi od społeczeństwa, stykali się z niespodziewanie serdecznymi reakcjami na ich „życzliwe słuchanie”. Annabel Faraday i Ken Plummer ilustrują to na przykładzie kilku z serii listów, które otrzymali: „Jeśli moje reakcje były impulsywne, to dlatego, że niespodziewanie przerwaliście mur mojej izolacji i mimowolnie uważam was za szczególnego rodzaju przyjaciół. Mam nadzieję, że wy też możecie tak o mnie myśleć”. A z późniejszego listu: „Dzisiejsza rozmowa z wami przyniosła mi wielką ulgę. Dziękuję wam za bycie tak życzliwymi słuchaczami i za sprawienie, że czułem się zrelaksowany”. I znów kilka miesięcy później: „Czuję, że przeciążam was i wykorzystuję jako ujście dla moich osobistych problemów, ale to jest jak wyciągnięcie korka...". Jako badacze, Faraday i Plummer rzeczywiście odkryli, że ich przejście z życzliwego obserwatora, „poprzez opiniującego słuchacza, do wspierającego spowiednika” było ciężarem, który mógł zużyć nieskończone pokłady energii, zważając na poważne problemy wielu dewiantów seksualnych, których opowieści nagrywali. Jednakże pozytywne zmiany, które zachodziły u niektórych informatorów, były równie uderzające: przykładem jest transwestyta, który zasugerował, że ma już „wystarczająco siły, by się publicznie ujawnić, co, jak uważał, nieuchronnie przyczyniłoby się do ostatecznego rozpadu jego ledwo trzymającego się małżeństwa, a czego - jak sam zasugerował - można by dokonać poprzez publikację historii jego życia"12. Zmiany, jakie badacze historii mówionej mogą zaobserwować, z pewnością nie będą zawsze tak barwne, ale mogą być równie ważne. Rosnące przekonanie, że nie tylko człowiek może przysłużyć się historii, lecz także historia może przysłużyć się człowiekowi jako takiemu, stanowiło jedno z głównych źródeł imponującej popularności terapii reminiscencyjnej w ostatnich latach.

Inną kwestią zyskującą zwolenników, jest dostrzegalna zmiana w podejściu do starzenia się wśród zawodowych opiekunów nad osobami starszymi. Wcześniej gerontolodzy zdecydowanie sprzeciwiali się reminiscencji. Widzieli oni „życie przeszłością” jako patologiczne, jako wycofanie się z bieżącej rzeczywistości, niezgodę na upływ czasu i starzenie, a nawet jako dowód organicznego uszkodzenia mózgu czy psychiczną „regresję do stanu dziecięcej zależności”. Założenie, że refleksja nad własną przeszłością

A. Ponsoby, English Diaries, London 1923, s. 8-9; A. Faraday, K. Plummer, Doing Life Histories, „Sociological Review”, 27 (1979), s. 773-798. 
i zaakceptowanie w ten sposób zmian może być niezbędne do utrzymania własnej tożsamości podczas przechodzenia przez typowe przemiany cyklu życia, jest logicznym wnioskiem wynikającym z podstawowego myślenia psychoanalitycznego, do czego przekonywał już Erikson. Jednak psychoanaliza osób starszych nie była raczej stosowana w praktyce. Największy wpływ na tę kwestię wywarł amerykański psychiatra-badacz Robert Butler, który w 1955 r. zaczął nagrywać wywiady w celu oceny zdrowia psychicznego osób starszych i podczas tych wywiadów zdał sobie sprawę z „dość wyraźnego [...] terapeutycznego efektu reminiscencji”. Poczynając od klasycznej dziś pracy The Life Review z 1963 r., Butler promował przekonanie, że reminiscencja jest normalna i zdrowa; że jest częścią uniwersalnego procesu ponownego oceniania dawnych konfliktów w celu odbudowania na nowo własnej tożsamości oraz że jest sposobem, w jaki starsi ludzie mogą sobie pomóc. Poprzez indywidualną rozmowę lub dyskusję grupową „mogą oni rozważyć swoje życie, aby rozwiązać, przeorganizować i na nowo zintegrować to, co ich martwi czy zajmuje ich myśli”. Osoby starsze, podobnie jak młodsze, potrzebują możliwości wyrażenia swoich odczuć, przegadania swoich problemów i przepracowania swoich żali; możliwości ponownego przemyślenia bolesnych lekcji rodzicielstwa w momencie, gdy chcą przekazać swoje moralne doświadczenie kolejnemu pokoleniu, a także możliwości „wyrażenia poczucia winy, żalu, niepewności, strachu i zakłopotania, które powiązane są z ich obawą, że nie spełnili się jako rodzice"13.

Wpływ przekonań Butlera rozszerzył się zarówno za pośrednictwem opublikowanego przez Amerykańskie Towarzystwo Psychiatryczne przewodnika Living History z 1970 r., jak i poprzez serię prac badaczy i terapeutów, którzy podejmowali próby przetestowania jego pomysłów. Po części przez brak zgody co do tego, co ma oznaczać normalna reminiscencja, oraz

P. Coleman, Issues in the Therapeutic Use of Reminiscece with Elderly People, [w:] Psychological Therapies for Elderly, red. I. Hanley, M. Gilhooly, London 1986, s. 4164; R. Dobrof, Introduction, [w:] The Uses of Reminiscence: New Ways of Working with Older Adults, red. M. Kaminsky, New York 1984; R. Butler, The Life Review: An Interpretation of Reminiscence in the Aged, „Psychiatry”, 26 (1963), s. 65-76; idem, The Life Review: An Unrecognized Bonanza, „International Journal on Aging and Human Development", 12 (1980/1981), s. 35-38; idem, Why Survive?, New York 1975, s. 412-414; A. Kleinman, Illness Narratives: Suffering, Healing and the Human Condition, New York 1988; Healing Stories: Narrative in Psychiatry and Psychotherapy, red. G. Roberts, J. Holmes, Oxford 1999. 
przez niewystarczający wzgląd na zgubne efekty utraty tożsamości spowodowane przez instytucje opieki, nic wystarczająco istotnego nie wypłynęło z tych badań ${ }^{14}$. Ewentualny praktyczny przełom dokonał się ostatecznie w Wielkiej Brytanii za pośrednictwem pracowników opieki społecznej i personelu szpitali, tworzących wspólny front w trosce o szybko wzrastającą obecnie liczbę starszych osób w potrzebie.

Były już co do tego pewne precedensy w praktyce pracy socjalnej, na przykład „księgi życia” składające się z dokumentów i fotografii, wydawane pierwotnie dla osieroconych dzieci, by pomóc im utrzymać lub odbudować poczucie własnej tożsamości po seriach chaotycznych przenosin pomiędzy instytucjami opiekuńczymi lub podczas pobytu w rodzinie zastępczej. Ostatnio księgi życia wykorzystuje się również do pomocy umysłowo upośledzonym dorosłym. Zdarzały się też przypadki spontanicznego wykorzystania reminiscencji w opiece społecznej nad starszymi osobami. Najważniejsza jednak była rosnąca świadomość, jak określił to Malcolm Johnson, „ogromnej arogancji” zajmujących się tym osób - z innej klasy społecznej, z innego pokolenia, o innych doświadczeniach życiowych - którzy z góry zakładali, że potrafią określić potrzeby swoich klientów bez wcześniejszego zrozumienia ich własnej diagnozy co do ich stanu. Oznaczało to spojrzenie na problemy wieku podeszłego z perspektywy doświadczeń życiowych samych osób starszych, poprzez słuchanie ich, „w celu rozpoznania ścieżki historii ich życia i tego, w jaki sposób ukształtowała ona ich obecne problemy i zmartwienia”. W ten sposób do głosu dopuszcza się osobiste priorytety każdej osoby dla późniejszych etapów jej życia, będące wynikiem całego życia „porażek i zwycięstw, lęków, spełnień i niezrealizowanych aspiracji”. Wielu pracowników opieki zdało sobie sprawę ze znaczenia przeszłości, gdy okazała się ona kluczem w szczególnie problematycznym przypadku, na przykład starszego mężczyzny, który nie jest w stanie sam się sobą zająć, ale uparcie odmawia przeniesienia do domu opieki. Jego opór staje się nagle zupełnie zrozumiały, gdy okazuje się, że dorastał w domu dziecka. W ostatnich latach znacznie wzrosło wykorzystanie podejścia opartego na historii

S. Merriam, The Concept and Function of Reminiscence: A Review of the Research, "Gerontologist”, 20 (1980), s. 604-609; V. Molinari, R.E. Reichlin, Life Review Reminiscence in the Elderly: A Review of the Literature, "International Journal on Aging and Human Development", 20 (1984/1985), s. 81-92. 
życia przy negocjowaniu wyborów dotyczących opieki domowej bądź prze-

niesienia do instytucji opiekuńczych. Krótko mówiąc: słuchanie okazało się zawodowo użyteczne ${ }^{15}$.

W międzyczasie Mick Knap, rządowy architekt zakwaterowania dla osób starszych, zaniepokojony niską jakością życia, którą zaobserwował w wielu odwiedzanych domach opieki, dostał możliwość przeprowadzenia eksperymentów z użyciem obrazów w celu skłonienia wycofanych, starszych osób do mówienia i odpowiadania. Pierwsze obrazy były artystyczne, jednak Knap odkrył, że stare obrazki przedstawiające sceny i wydarzenia - na przykład wnętrza domów, abdykację Edwarda VIII, Strajk Generalny czy inne demonstracje - sprawdzały się jeszcze lepiej. Podobnie rzecz miała się ze starą muzyką dopasowaną do obrazów. W 1980 r. projekt „Przypomnienie” (ang. Recall) przejęty został przez Wydział Edukacji o Pomocy Starszym (ang. Help the Aged Education Department), gdzie Joanna Bornat skonfrontowała go ze swoim doświadczeniem badaczki historii mówionej. W ciągu roku wydano serię sześciu sekwencji nagrań i slajdów, łączących muzykę, śpiew i mówione wspomnienia, do wykorzystania w grupach osób starszych.

Tanie i proste w użyciu zestawy, wymagające jedynie odtwarzacza, projektora i białej ściany, wydawane w ramach projektu „Przypomnienie”, okazały się ogromnie skuteczne, stanowiąc natychmiastową demonstrację efektywności idei Butlera w praktyce. Reminiscencja przynosiła nadzwyczajne rezultaty $\mathrm{w}$ wielu różnych przypadkach, od osób starszych mieszkających w domach i gromadzących się w centrach aktywności i klubach seniora, przez przewlekle chorych zagrożonych umieszczeniem w domu opieki, do tych cierpiących na głęboką depresję, demencję czy nawet chorych psychicznie pacjentów szpitali. W zwykłej grupie nieco znudzonych, wycofanych, starych ludzi nagle zmienia się atmosfera: po uruchomieniu nagrań i slajdów osoby te zaczynają rozmawiać, śpiewać w rytm odtwarzanych piosenek, a po zakończeniu pokazu rozmowy toczą się dalej; niektórzy mówią, a inni się przysłuchują. Co jeszcze bardziej zadziwiające, osoby, które nie odzywały się miesiącami, nagle zaczynają rozmawiać z innymi; osoby kompletnie zobojętniałe zaczynają wybijać stopą rytm muzyki; starsza kobieta, która tak bardzo się zaniedbała, zaczyna ponownie przykładać

D. Frost, K. Taylor, Life Story Books: This is My Life, „Community Care”, 7 (sierpień 1986), s. 28; M. Johnson, That was Your Life: A Biographical Approach to Later Life, [w:] An Ageing Population, red. V. Carver, P. Liddiard, London 1979, s. 147-161. 
wagę do swojego wyglądu; pogrążony w depresji starszy mężczyzna, wymienia wspomnienia z byłym współpracownikiem i się uśmiecha. Równie istotny jest wpływ tych zmian na innych. Personel dostrzega, że coś da się zrobić; krewni zaczynają odwiedzać seniorów częściej i zostają na dłużej. W prostych słowach: „Przypomnienie” stwarza wspólny punkt zaczepienia, a gdy komunikacja odradza się na nowo, ludzie ponownie odkrywają siebie nawzajem jako istoty ludzkie.

Pierwsza seria zestawów "Przypomnienia” - na temat "Dzieciństwa” w pierwszej dekadzie XX w., „Młodości” w latach 20. XX w., „Lat 3o. XX w.”, obu wojen i tak dalej - sprzedała się w 1500 egzemplarzach w ciągu trzech lat. Od tego czasu wiele okręgów wydało swoje własne, lokalne zestawy. Regularnie odbywają się szkolenia w zakresie wykorzystania reminiscencji dla pielęgniarek, pracowników opieki, osób zajmujących się terapią zajęciową i innych zawodowo i w ramach wolontariatu zajmujących się osobami starszymi. Terapia reminiscencyjna stała się ożywczą falą, katalizatorem zmiany w opiece nad osobami w podeszłym wieku, czymś zdolnym do zmiany przekonań na wiele różnych prostych, lecz w ogólnym rozrachunku bardzo znaczących sposobów. John Adams porozwieszał na ścianach oddziału opieki długoterminowej w południowym Londynie stare plakaty, czym sprowokował do mówienia zarówno pacjentów, jak i odwiedzających: „pacjenci opowiadają odwiedzającym ich osobom, jak odróżniali brytyjskie statki powietrzne od niemieckich podczas pierwszej wojny światowej”. Oddziały opiekuńcze powinny otrzymywać nazwy, które będą coś mówić starszym pacjentom, na przykład po gwiazdach widowisk muzycznych, a nie po świętych czy lokalnych fundatorach; powinny one też być udekorowane zgodnie z takim założeniem, aby „reminiscencja przestała być czymś specjalnym, a stała się częścią życia na oddziale". Andrew Norris i Mohammed Abu El Eileh zabrali grupę wrażliwych pacjentów psychogeriatrii ze szpitala w Dartford w miejsca wskazane przez starsze osoby podczas sesji terapeutycznej: grupa odwiedziła dawne miejsca pracy, domy, szkoły i puby. „Odzew ze strony naszych pacjentów był zdumiewający”. Dyskusja grupowa zaowocowała odkryciem wśród pacjentów trzech byłych muzyków, dla których udało się zakupić instrumenty, co zapewniło rozrywkę na oddziale. Aktywniejsze grupy zajęły się wydaniem lokalnych broszurek i organizowaniem wystaw ${ }^{16}$.

J. Adams, Reminiscence in the Geriatric Ward: An Undervalued Resource, "Oral History”, 12 (1984), nr 2, s. 54-59; J. Lesser [et al.], Reminiscence Group Therapy with 
Wciąż nie jest jasne, jak użyteczna, w ściśle medycznym znaczeniu, może być reminiscencja. Z pewnością nie wyleczy ona chorób, takich jak demencja, lecz „może po prostu uczynić życie w szpitalu odrobinę bardziej znośnym i nadać mu sens". Równie oczywiste jest, że konkretne zastosowanie i efekty reminiscencji będą różne, zależnie od tego, czy kontekstem jej wykorzystania będzie praca społeczna z osobami starszymi w ich własnych domach lub domach opieki czy też w szpitalu; bądź praca indywidualna. Peter Coleman zaznacza, że reminiscencja nie odpowiada wszystkim w tym samym stopniu. Jego własne badania są przypadkiem szczególnym, gdyż udało mu się skontrolować w późniejszym czasie stan ośmiu z pięćdziesięciu jeden ocalałych, z którymi przeprowadzał wywiady w domu opieki w Londynie dziesięć lat wcześniej. Pierwsze wyniki badania wskazały, że dwadzieścia jeden osób było „szczęśliwymi wspominaczami” i z przyjemnością mówiło o swojej przeszłości. Było też jednak szesnaście osób, które nie widziały sensu w reminiscencji, bo aktywnie radziły sobie w życiu na inne sposoby. Ci „szczęśliwi wspominacze” okazali się najbardziej odporną grupą, a grupa aktywnie sprzeciwiających się reminiscencji składała się z garstki osób o niskim morale, jak na przykład samotny były więzień; częściej jednak takie osoby były po prostu zajęte różnymi aktywnościami, a reminiscencja była dla nich stratą cennego czasu. Bardziej uderzający kontrast widoczny jest jednak pomiędzy dwoma pozostałymi grupami. Osiem osób było „kompulsywnymi wspominaczami”, a ich „zadumę nad przeszłością zdominowały wspomnienia żalu”; mówili dużo, ale źle się z tym czuli. Prognozy dla nich nie były dobre i wskazywały na zwiększony psychiczny niepokój. Takim osobom terapia grupowa mogłaby zrobić krzywdę; potrzebowali oni umiejętnie przeprowadzonej indywidualnej terapii. Równie ponure były rokowania dla szóstki osób, która unikała wspominania, gdyż w głębszą depresję wpędzało ich to, że teraźniejszość wydawała się im znacznie gorsza niż przeszłość. Zwykle takie osoby doznały w niedawnym czasie ogromnej straty, na przykład utraciły bliską osobę, i nie mogły poradzić sobie z przystosowaniem się do wdowieństwa i samotnego życia bez ich towarzysza życia. W tym wypadku również konieczna

Psychotic Geriatric Patients, „Gerontologist”, 21 (1981), s. 291-296; A. Norris, M. Abu El Eileh, Reminiscence Groups: A Therapy for both Elderly Patients and their Staff, "Nursing Times”, 78 (1982), s. 1368-1369. Zob. też: A. Norris, Reminiscence with Elderly People, London 1986; M. O'Connor, Generation to Generation, London 1993; F. Gibson, Reminiscence and Recall: A Guide to Good Practice, London 1994. 
170 była indywidualna terapia, której te osoby nie otrzymały: ci, którzy jeszcze żyli, dziesięć lat później wciąż cierpieli na depresję. Podsumowując: nie istnieją automatycznie dobre rozwiązania: „każdego należy potraktować w sposób szczególny"17.

W tym właśnie tkwi sedno sprawy. Terapia reminiscencyjna stanowi panaceum w takim samym stopniu, co psychoanaliza. Podstawa ich mocy dokonywania przemian - podobnie jak w wypadku samej historii mówionej - jest dość prosta: uważne słuchanie tego, co starsi ludzie mają do powiedzenia. Właśnie w taki sposób smutna, trudna i marudna biała osoba może stać się w pełni sobą, a nawet osobą o podobnych doświadczeniach, co młoda pielęgniarka pochodząca z Karaibów. Jeśli personel opiekuńczy nie podejmie wysiłku poznania swoich pacjentów, bardzo łatwo stają się oni jedynie ciałami, które trzeba nakarmić, napoić, oporządzić i podtrzymać przy życiu. Komunikacja może na powrót uczynić z nich ludzi.

Co widzicie, pielęgniarki, powiedzcie: co widzicie,

O czym myślicie, gdy na mnie patrzycie?

Zrzędliwa starucha, z powolnym myśleniem,

Niepewna nawyków, z nieobecnym spojrzeniem,

Która upuszcza jedzenie, nie chce odpowiadać,

Kiedy mówicie „choć się proszę postarać”...

Czy tak właśnie myślicie, czy to widzicie?

Otwórzcie oczy, to nie na mnie patrzycie...

Jestem dziesięciolatką z troskliwymi rodzicami,

z braćmi i siostrami, bardzo się kochamy.

Jestem szesnastolatką, niemogącą zagrzać miejsca,

Marzącą, że ją spotka miłość, ta największa...

Mam lat dwadzieścia pięć i mam już własne młode,

Które mnie potrzebują, daję im bezpieczeństwo i swobodę...

Krótko po czterdziestce - moich dzieci już nie ma,

Mój partner od żałoby wstrzymuje kiedy trzeba...

Przychodzą czarne chmury, mój mąż umiera,

P. Coleman, Issues in the Therapeutic Use of Reminiscence...; idem, The Past in the Present: A Study of Elderly People's Attitiudes to Reminiscence, "Oral History", 14 (1986), nr 1, s. 50-57. Zob. też: idem, Elderly People and the Reminiscence Process, London 1986; „Oral History”, 17 (1989), nr 2: tom Reminiscence; Reminiscence Reviewed: Evaluations, Achievements, Perspectives, red. J. Bornat, Buckingham 1994. 
Patrzę w przyszłość i strach na mnie naciera...

Teraz jestem już stara; natura, jakby chciała dobić,

Ponurym żartem na starość głupca z ciebie robi...

Lecz w tej starej skorupie wciąż żyje dziewczyna,

I czasem moje serce na chwilę odżywa,

Pamiętam swą pracę, pamiętam cierpienie,

I kocham i na nowo przeżywam swe istnienie...

Oczy otworzyć niech więc pielęgniarka raczy,

By nie starą zrzędę, ale mnie zobaczyć ${ }^{18}$.

18 H. Hazan, The Limbo People, London 1980, s. 27-28. Prawdziwe źródło tego wiersza, który był cytowany w wielu miejscach, jest niejasne, ale do kontekstu pasujące jego mityczne pochodzenie z Londyńskiego centrum opieki nad osobami starszymi. 